\title{
CARD15/NOD2 Is Not a Predisposing Factor for Necrotizing Enterocolitis
}

\author{
Habib Zouali · Arnaud Bonnard · Pascal De Lagausie • \\ Caroline Farnoux · Yves Aigrain · Jean-Pierre Cezard · \\ Michel Peuchmaur $\cdot$ Jean-Pierre Hugot $\cdot$ Dominique Berrebi
}

Published online: 19 December 2008

(C) Springer Science+Business Media, LLC 2008

\section{Erratum to: Dig Dis Sci}

DOI 10.1007/s10620-005-2915-z

This article was published with the given name and family name for each of the authors in reverse order. The correct order, given name followed by family name, is shown in this erratum.

The online version of the original article can be found under doi:10.1007/s10620-005-2915-z.

H. Zouali $(\bowtie)$

Fondation Jean Dausset-CEPH, 27, Rue Juliette Dodu,

75010 Paris, France

e-mail: habib@cephb.fr

A. Bonnard · P. De Lagausie - Y. Aigrain

Service de Chirurgie Pédiatrique, Paris, France

P. De Lagausie · M. Peuchmaur - D. Berrebi

EA3102, Université Paris 7, Paris, France

C. Farnoux

Service de Néonatologie, Paris, France

J.-P. Cezard · J.-P. Hugot

Service de Gastroentérologie Pédiatrique, Paris, France

M. Peuchmaur - D. Berrebi

Service d'Anatomie et Cytologie Pathologiques, Paris, France

J.-P. Hugot

INSERM U458, Hôpital Robert Debré, Paris, France 